\title{
Noble Metal Added Tin Oxide VOC Sensors as Nonanal Detection for Exhaled Breath Air Monitoring
}

\author{
Toshio Itoh ${ }^{1}$, Takaomi Nakashima ${ }^{1}$, Noriya Izu', Woosuck Shin ${ }^{1}$, \\ Yasuhiro Setoguchi ${ }^{2}$, Kimiko Kato ${ }^{2}$, Masashi Toyota ${ }^{2}$ \\ ${ }^{1}$ National Institute of Advanced Industrial Science and Technology (AIST), \\ Shimo-shidami, Moriyama-ku, Nagoya 463-8560, Japan \\ ${ }_{2}^{2}$ Figaro Engineering Inc., Senbanishi, Mino, Osaka 562-8505, Japan
}

\begin{abstract}
:
We have investigated the VOCs-sensing properties of $\mathrm{Pt}, \mathrm{Pd}$, Au-loaded $\mathrm{SnO}_{2}$ thick film for exhaled breath air. It has been reported that breaths of lung cancer patients include long methylene chain-aldehydes, such as nonanal. The Pt, $\mathrm{Pd}$, Au-loading for $\mathrm{SnO}_{2}$ type gas sensors is advantage for detect to low concentration VOCs. The $\mathrm{Pt}, \mathrm{Pd}, \mathrm{Au} / \mathrm{SnO}_{2}$ element shows higher response to nonanal than a non-loaded $\mathrm{SnO}_{2}$ element. The combustion of nonanal molecules on the surface of $\mathrm{SnO}_{2}$ grains is assisted by added noble metals. A nonanal-sensing property of the The $\mathrm{Pt}, \mathrm{Pd}, \mathrm{Au} / \mathrm{SnO}_{2}$ depend on an annealing temperature. We installed the sensor element to a prototype of breath monitor with gas-chromatograph system, and analyzed mixed gas including three long methylene chain-aldehyde gases.
\end{abstract}

Key words: lung cancer, aldehydes, nonanal, $\mathrm{SnO}_{2}$, multi-noble metals addition

\section{Introduction}

Human exhaled breath air includes many kinds of volatile organic compounds (VOCs), which depend on such as metabolism, mouth odor, and diseases. Parts of VOCs in exhaled breath air have been regarded as biomarkers of diseases. Many researchers have investigated the biomarkers of lung cancer [1-3], and developed analytical system for exhaled breath air $[2,4]$. Recently, Fuchs et al. have reported concentrations of aldehyde gases in exhaled breath airs from healthy people, smokers, and lung cancer patients. Breaths of lung cancer patients include aldehydes whose consist of aldehyde group with saturated methylene chain, such as pentanal, hexanal, octanal, and nonanal [3]. Concentration of nonanal is specifically higher than that of other aldehyde gases. Although the concentrations of these aldehyde gases are ppb level [3]. A gas chromatograph-mass spectrometer (GC/MS) with a gas condense equipment can detect low concentrate VOCs. However, the GC/MS system is so expensive that inexpensive detectors, such as portable VOC detectors, are desirable for a periodic medical inspection and a health screening.

$\mathrm{SnO}_{2}$ is one of the best materials for VOC sensors because of its high sensitivity. In cases of sub-ppm level, the $\mathrm{SnO}_{2}$-based gas sensors showed lower response to aliphatic hydrocarbons, halogenated hydrocarbons, and aromatic hydrocarbons than to other VOCs, such as alcohol and esters [5]. It has been reported that the addition of $\mathrm{Pt}, \mathrm{Pd}$, and $\mathrm{Au}$ to $\mathrm{SnO}_{2}$ thick films improve the sensitivity to aliphatic, halogenated, and aromatic hydrocarbons, respectively [6]. Therefore, it is expected that the $\mathrm{Pt}, \mathrm{Pd}$, and $\mathrm{Au}$ loaded $\mathrm{SnO}_{2}$ has advantage for the detection of the gas of long methylene chain-aldehyde group.

In this study, we have optimized film thickness and annealing temperature of the $\mathrm{Pt}$, $\mathrm{Pd}$, and $\mathrm{Au}$ loaded $\mathrm{SnO}_{2}$-based sensors as nonanal sensors, and install the sensors in a prototype of breath monitor with gaschromatograph system.

\section{Experimental}

\section{(1) Sensing property}

Figure 1 shows a scheme of preparation for elements. $\mathrm{Pt}, \mathrm{Pd}$, and $\mathrm{Au}$ colloid suspensions (particle size: $2-4 \mathrm{~nm}$ ) were added to the $\mathrm{SnO}_{2}$ powder (particle size: $100 \mathrm{~nm}$ ). The contents of $\mathrm{Pt}, \mathrm{Pd}$, and $\mathrm{Au}$ were controlled $1 \mathrm{wt} \%$ relative to that of the $\mathrm{SnO}_{2}$. The mixture was stirred and dried, subsequently burned at $400{ }^{\circ} \mathrm{C}$ for $2 \mathrm{~h}$. The resulting powder was added into an organic dispersant (vehicle) to obtain a paste. The ratio powder/vehicle of the paste 
was changed from $1 / 8$ to $1 / 128$ to control the film thickness. The pastes were subsequently dropped on $5 \times 9.5 \mathrm{~mm}^{2}$ Si substrates with comb-type $\mathrm{Pt}$ electrodes (10 $\mu \mathrm{m}$ gap), which was patterned on front side. On the backside of the substrate, the Pt heater was patterned. The substrates were annealed at $425^{\circ} \mathrm{C}$ for $2 \mathrm{~h}$. We obtained $\mathrm{Pt}, \mathrm{Pd}, \mathrm{Au} / \mathrm{SnO}_{2}$ sensor elements, as shown in Fig. 2.

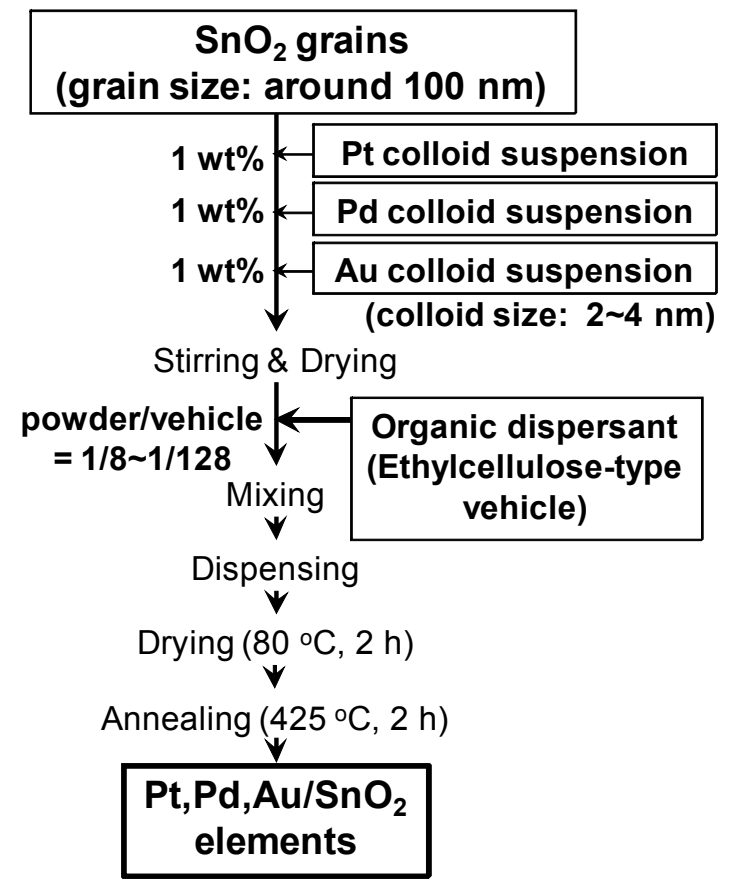

Fig. 1. Scheme of preparation for $\mathrm{Pt}, \mathrm{Pd}, \mathrm{Au} / \mathrm{SnO}_{2}$ sensor elements.

Surface and cross sections of the $\mathrm{Pt}, \mathrm{Pd}, \mathrm{Au} / \mathrm{SnO}_{2}$ thick films were observed by a JEOL JSM-6335FM field-emission scanning electron microscopy (FE-SEM). Thicknesses of the $\mathrm{Pt}, \mathrm{Pd}, \mathrm{Au} / \mathrm{SnO}_{2}$ thick films were estimated from cross sections of FE-SEM images.

The gas sensing properties of the elements were measured using a flow-type gas sensing measurement apparatus. The elements were heated at 250 and $300{ }^{\circ} \mathrm{C}$ by their $\mathrm{Pt}$ heaters. Nonanal gas was generated from liquid nonanal by a Gastec PD-1B permeator. The concentration of nonanal was controlled to 9.5 , $1.0,0.18$, and $0.055 \mathrm{ppm}$. The total flow rate was kept at $200 \mathrm{~mL} / \mathrm{min}$. The sensor response $(S)$ is defined as equation (1),

$S=\frac{R_{a}}{R_{g}}$

where $R_{a}$, and $R_{g}$ are the electrical resistance in pure air and nonanal gas, respectively. After the nonanal-sensing property measurement, the elements were annealed at $500^{\circ} \mathrm{C}$ for $2 \mathrm{~h}$.
The $500^{\circ} \mathrm{C}$-annealed-elements were measured the nonanal-sensing property again.

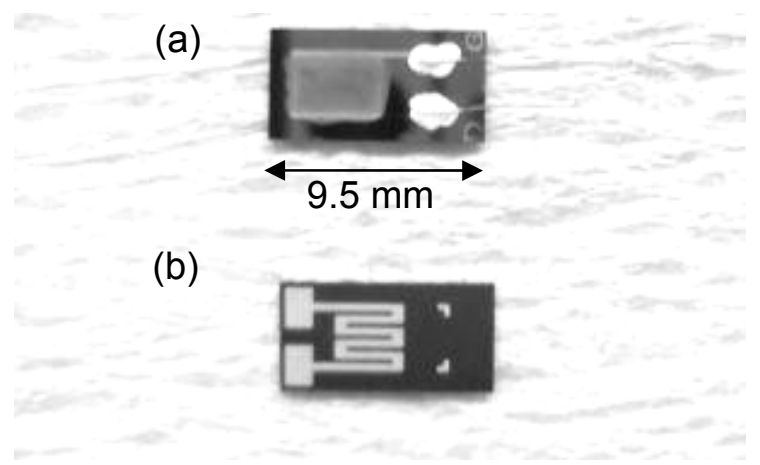

Fig. 2. Sensor elements: (a) $\mathrm{SnO}_{2}$ thick film formed on comb-type Pt electrode (10 $\mu \mathrm{m}$ gap) on front side, (b) Pt heater on back side.

\section{(2) Prototype system}

For a prototype system, we remodeled the sensor element to $4 \times 4 \mathrm{~mm}^{2}$. The sensor element was hung on a metal stem by gold wires, as shown in Fig. 3. The $\mathrm{Pt}, \mathrm{Pd}, \mathrm{Au} / \mathrm{SnO}_{2}$ thick film and $\mathrm{Pt}$ heater were applied voltage via pins of the stem and the gold wires. The stem was installed in the prototype system.

Fig. 4 shows flow paths of the prototype system. The prototype system has an adsorption agent for condensation of VOCs and a gas chromatography (GC) column for separation of many kinds of VOCs. First, sample gas including VOCs in a gas bag is aspirated, and condensed to the adsorption agent. Subsequently, the adsorption agent is heated and pure air as a carrier gas is flowed to the adsorption agent. Re-gasification VOCs are separated each kind of VOC and detected by the sensor element at each retention time. In this study, we prepared a mixed gas included $500 \mathrm{ppb}$ of heptanal, $500 \mathrm{ppb}$ of octanal, and $500 \mathrm{ppb}$ of nonanal for the evaluation of VOCsseparation.

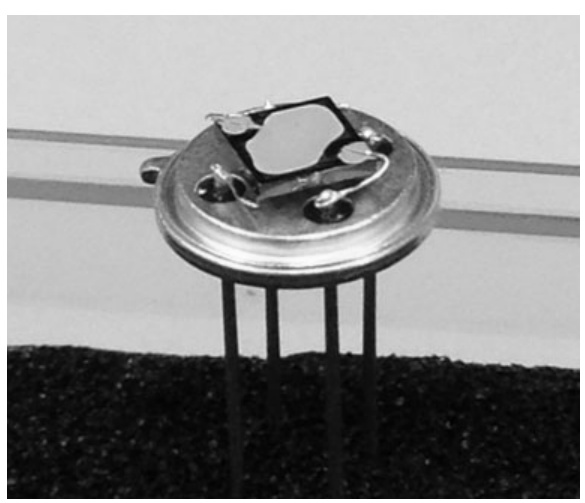

Fig. 3. Sensor element for prototype system. Size of the sensor element substrate is $4 \times 4 \mathrm{~mm}^{2}$. 


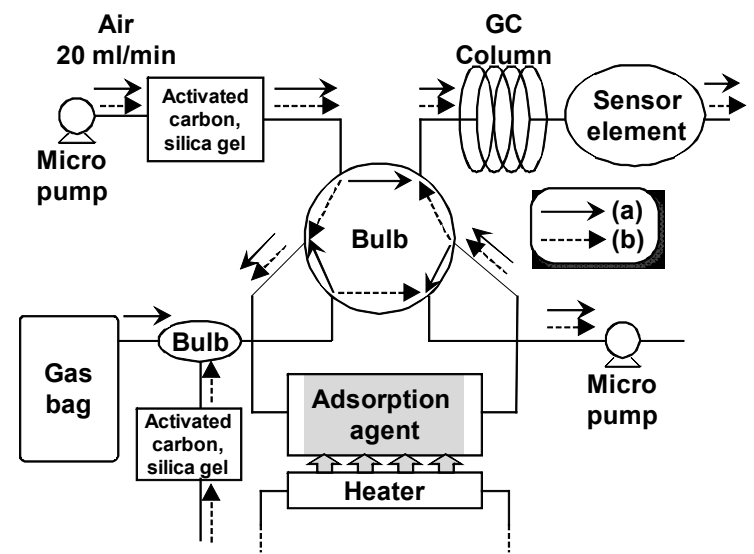

Fig. 4. Flow paths of the prototype system. Two kinds of arrows indicate flow routes: (a) VOCs-condensing path, and (b) analysis path.

\section{Results and Discussion}

\section{(1) Sensing property}

Fig. 5 shows SEM images of the $\mathrm{Pt}, \mathrm{Pd}, \mathrm{Au} / \mathrm{SnO}_{2}$ thick film on surface and edge sections. The ratio powder/vehicle of the element in Fig. 5 is $1 / 16$. The SEM images show non-aggregation of the $\mathrm{Pt}, \mathrm{Pd}, \mathrm{Au} / \mathrm{SnO}_{2}$ grains and the $\mathrm{Pt}, \mathrm{Pd}, \mathrm{Au} / \mathrm{SnO}_{2}$ thick film has a lot of pores and uniformity thickness. We confirmed that the thickness of the $\mathrm{Pt}, \mathrm{Pd}, \mathrm{Au} / \mathrm{SnO}_{2}$ thick films can be controlled by the powder/vehicle ratios reproducibility.
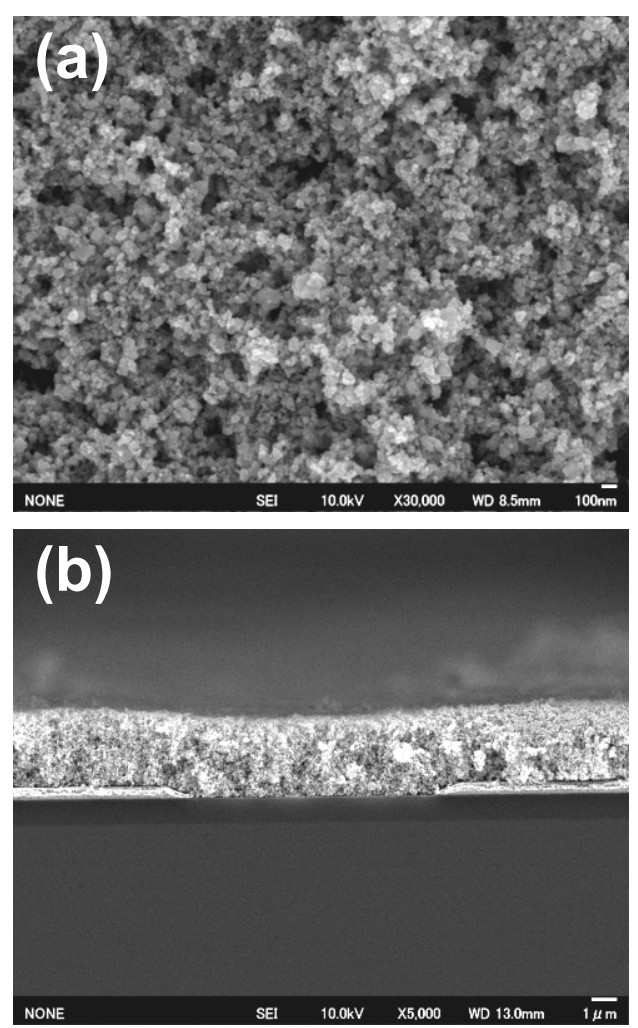

Fig. 5. SEM images of $\mathrm{Pt}, \mathrm{Pd}, \mathrm{Au} / \mathrm{SnO}_{2}$ thick film on (a) surface and (b) cross sections.
Fig. 6 shows the dynamic resistance responses of the $\mathrm{Pt}, \mathrm{Pd}, \mathrm{Au} / \mathrm{SnO}_{2}$ element. The $\mathrm{Pt}, \mathrm{Pd}, \mathrm{Au} / \mathrm{SnO}_{2}$ element was annealed at 500 ${ }^{\circ} \mathrm{C}$ for $2 \mathrm{~h}$. The resistances of the $\mathrm{Pt}, \mathrm{Pd}, \mathrm{Au} / \mathrm{SnO}_{2}$ element decreased and reached to saturation values during flowing of nonanal gases for less than $1 \mathrm{~min}$. It is found that $\mathrm{Pt}, \mathrm{Pd}, \mathrm{Au} / \mathrm{SnO}_{2}$ element exhibited distinct responses to dozen ppb of nonanal. Moreover, the $\mathrm{Pt}, \mathrm{Pd}, \mathrm{Au} / \mathrm{SnO}_{2}$ element after annealed at $500{ }^{\circ} \mathrm{C}$ shows stronger response to nonanal than the element before annealed at $500^{\circ} \mathrm{C}$.

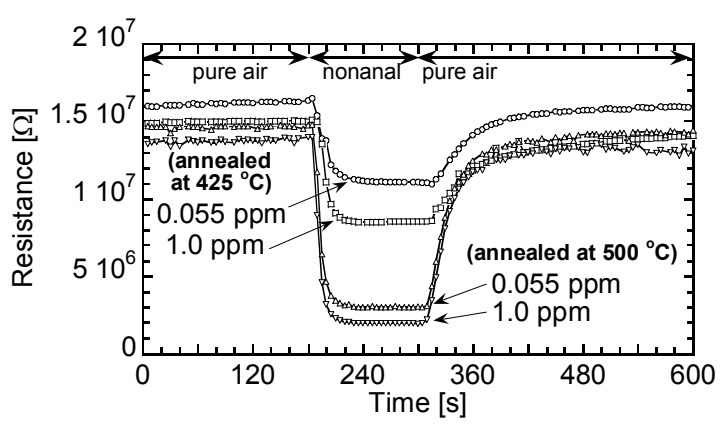

Fig. 6. Dynamic resistance responses of the $\mathrm{Pt}, \mathrm{Pd}, \mathrm{Au} / \mathrm{SnO}_{2}$ thick film (Thickness: $\left.2.8 \mu \mathrm{m}\right)$ to 1 ppm and 0.055 ppm of nonanal gases.

Fig. 7 shows the sensor responses of the $\mathrm{Pt}, \mathrm{Pd}, \mathrm{Au} / \mathrm{SnO}_{2}$ element and a non-added $\mathrm{SnO}_{2}$ element to nonanal gases. The non-added $\mathrm{SnO}_{2}$ as well as the $\mathrm{Pt}, \mathrm{Pd}, \mathrm{Au} / \mathrm{SnO}_{2}$ elements, after annealed at $500{ }^{\circ} \mathrm{C}$, shows higher response to nonanal than the $\mathrm{Pt}, \mathrm{Pd}, \mathrm{Au} / \mathrm{SnO}_{2}$ before annealed at $500{ }^{\circ} \mathrm{C}$. The results can be explained that the annealing temperature is the most important factor for detection to nonanal on the $\mathrm{SnO}_{2}$ system.

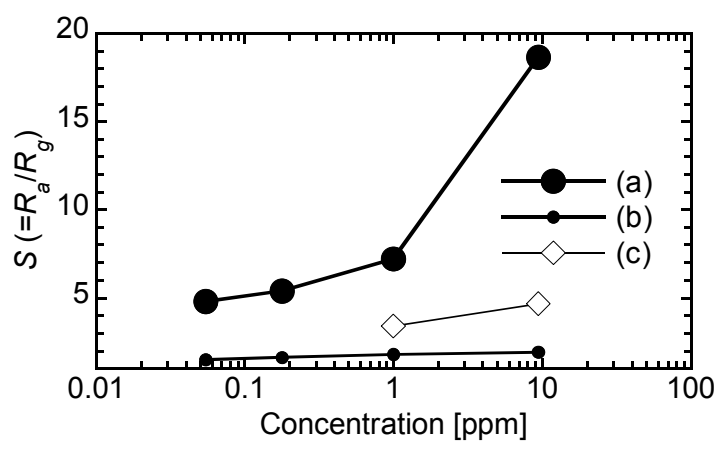

Fig. 7. Sensor response values to nonanal gas: (a) (a) $\mathrm{Pt}, \mathrm{Pd}, \mathrm{Au} / \mathrm{SnO}_{2}$ (Thickness: $2.8 \mu \mathrm{m}$ ) before annealing at $500{ }^{\circ} \mathrm{C}$, (b) $\mathrm{Pt}, \mathrm{Pd}, \mathrm{Au} / \mathrm{SnO}_{2}$ (Thickness: $2.8 \mu \mathrm{m}$ ) after annealing at $500{ }^{\circ} \mathrm{C}$, and (c) $\mathrm{SnO}_{2}$ (Thickness: $1.9 \mu \mathrm{m}$ ) thick films after annealed at $500{ }^{\circ} \mathrm{C}$. Sensor temperatures are $250^{\circ} \mathrm{C}$.

It can be explained that the decrease of electron depleted layer extremely affected the resistance change of the $\mathrm{Pt}, \mathrm{Pd}, \mathrm{Au} / \mathrm{SnO}_{2}$ 
because the neck growth of the $\mathrm{SnO}_{2}$ grains seems to be promoted by annealing at $500{ }^{\circ} \mathrm{C}$. Moreover, the $\mathrm{Pt}, \mathrm{Pd}, \mathrm{Au} / \mathrm{SnO}_{2}$ element shows higher response to nonanal than the $\mathrm{SnO}_{2}$ element. The results suggest that the combustion of nonanal molecules on the surface of $\mathrm{SnO}_{2}$ grains is assisted by the added noble metals.

\section{(2) Prototype system}

Fig. 8 shows sensor response from the $\mathrm{Pt}, \mathrm{Pd}, \mathrm{Au} / \mathrm{SnO}_{2}$ element in the prototype system. The prototype system can separate each VOC, which has closely resemble molecular structure; $\mathrm{CH}_{3}\left(\mathrm{CH}_{2}\right)_{\mathrm{n}-2} \mathrm{CHO}, \mathrm{n}=7$ (heptanal), 8 (octanal), and 9 (nonanal).

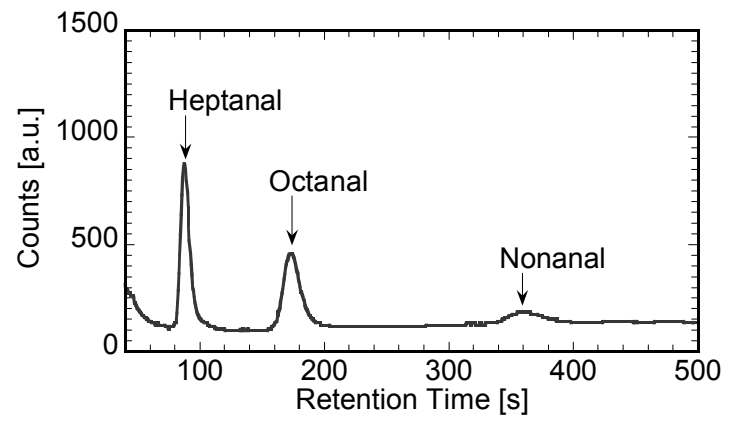

Fig. 8. Sensor response from the $\mathrm{Pt}, \mathrm{Pd}, \mathrm{Au} / \mathrm{SnO}_{2}$ element in the prototype system.

\section{Conclusion}

The $\mathrm{Pt}, \mathrm{Pd}, \mathrm{Au} / \mathrm{SnO}_{2}$ elements were prepared to drop pastes, consisting of $\mathrm{Pt}, \mathrm{Pd}, \mathrm{Au} / \mathrm{SnO}_{2}$ powder and an organic dispersant, on the substrate. We observed the $\mathrm{Pt}, \mathrm{Pd}, \mathrm{Au} / \mathrm{SnO}_{2}$ thick film has a lot of pores and uniformity thickness, and $\mathrm{Pt}, \mathrm{Pd}, \mathrm{Au} / \mathrm{SnO}_{2}$ grains do not aggregate in the $\mathrm{Pt}, \mathrm{Pd}, \mathrm{Au} / \mathrm{SnO}_{2}$ thick films. The $\mathrm{Pt}, \mathrm{Pd}, \mathrm{Au} / \mathrm{SnO}_{2}$ element shows higher response to nonanal than a non-loaded $\mathrm{SnO}_{2}$ element. A nonanal sensing property of the $\mathrm{Pt}, \mathrm{Pd}, \mathrm{Au} / \mathrm{SnO}_{2}$ depend on an annealing temperature. The $\mathrm{Pt}, \mathrm{Pd}, \mathrm{Au} / \mathrm{SnO}_{2}$ elements after annealed at $500{ }^{\circ} \mathrm{C}$ shows higher response to nonanal than the $\mathrm{Pt}, \mathrm{Pd}, \mathrm{Au} / \mathrm{SnO}_{2}$ before annealed at $500{ }^{\circ} \mathrm{C}$. It is plausibly explained that the combustion of nonanal molecules on the surface of $\mathrm{SnO}_{2}$ grains is assisted by added noble metals, and the decrease of electron depleted layer extremely affected the resistance-decreased of the $\mathrm{Pt}, \mathrm{Pd}, \mathrm{Au} / \mathrm{SnO}_{2}$ because the $\mathrm{SnO}_{2}$ grains are more combined by annealing at $500{ }^{\circ} \mathrm{C}$. The prototype system with the $\mathrm{Pt}, \mathrm{Pd}, \mathrm{Au} / \mathrm{SnO}_{2}$ element can detect three kinds of aldehydes separately.

\section{Acknowledgements}

This work was supported by the project "Development Project for Extremely-Early
Diagnostics Technologies for Human Diseases" of Aichi prefecture, Japan.

\section{References}

[1] M. Phillips, K. Gleeson, J. M. B. Hughes, J. Greenberg, R. N. Cataneo, L. Baker, Lancet, 353, 1930-1933 (1999); doi: 10.1016/S01406736(98)07552-7

[2] G. Peng, U. Tisch, O. Adams, M. Hakim, N. Shehada, Y. Y. Broza, S. Billan, R. A.-Bortnyak, A. Kuten, H. Haick, Nature Nanotech., 4, 669-673 (2009); doi: 10.1038/NNANO.2009.235

[3] P. Fuchs, C. Loeseken, J. K. Schubert, W. Miekisch, Int. J. Cancer 126, 2663-2670 (2010); doi: 10.1002/ijc.24970

[4] M. Westhoff, P. Litterst, L. Freitag, W. Urfer, S. Bader, J.-I. Baumbach, Thorax, 64, 744-748 (2009); doi: 10.1136/thx.2008.099465

[5] M. Kadosaki, Y. Sakai, I. Tamura, I. Matsubara, T. Itoh, Electro. Commun. Jpn., 93, 34-41 (2008); doi: 10.1002/ecj.10190

[6] Y. Sakai, M. Kadosaki, I. Matsubara, T. Itoh, J. Ceram. Soc. Jpn., 117, 1297-1301 (2009) 